\title{
Hiperemezis Gravidarumlu Hastalarda Anksiyete ve Depresyon Test Skorları
}

\author{
Depression And Anxiety Test Scores In Patients With \\ Hyperemesis Gravidarum
}

\section{Esin Kasap}

Özel Tınaztepe Hastanesi Kadın Hastalıkları ve Doğum Kliniği, Izmir

Gelis Tarihi/Received: 04 Şubat 2018 Kabul Tarihi/Accepted: 10 Mayıs 2018

\begin{abstract}
Öz
Amaç: Hiperemezis gravidarum (HG), gebeliğin erken döneminde, aşırı, tedavi edilmesi zor bulantı ve kusma ile kendini gösteren bir bozukluktur. Patogenezi açık değildir. Bununla birlikte, anksiyete, depresyon ve HG arasındaki ilişkiyi araştıran çalışmalar vardır. Ancak, hiçbiri yeterince bu bağlantıyı açıklığa kavuşturmamıştır. Bu çalışmada, Türk popülasyonunda Beck depresyon ve anksiyete envanteri puanlama sistemi kullanılarak hiperemezis gravidarum olan gebelerin depresyon ve anksiyete düzeylerinin belirlenmesi amaçlanmıştır.

Hastalar ve Yöntem: Prospektif kesitsel çalışma Ocak 2011 ile Haziran 2013 arasında Hastanemiz Kadın Hastalıkları ve Doğum Bölümü'nde gerçekleştirildi.Çalışma grubunu hiperemezis gravidarumlu 50 gebe hasta oluştururken, kontrol grubunu daha önce bulantı kusması olmayan 50 sağlıklı gebe oluşturmaktaydı. Kontrol ve hasta grupları obstetrik detaylar,yas ve vücut kitle indexi değerleri açısından eşleştirildi. Hastaların tümüne,serum TSH de dahil olmak üzere temel laboratuvar araştırmaları yapıldı.

Bulgular: Her iki grupta da demografik ve obstetrik parametreler ve başlangıçtaki laboratuvar incelemeleri açısından farklılık olmamasına rağmen, HG grubunda ortalama serum AST ve TSH düzeyleri anlamlı olarak yüksekti $(p=0.015)$ ve $(p=0.001)$. Ek olarak, HG grubunun BDI ve BAI skorları kontrol grubuna göre anlamlı derecede daha yüksekti $(p=0.0001$ ve $p=0.0001$, sırasıyla)

Sonuç: Sonuçlarımız, psikolojik stressin HG un nedenlerinden biri olabileceğini göstermiştir.Bu nedenle, gebelik sırasında HG lu hastaların tıbbi koşulları kadar duygu durumları da dikkate alınmalıdır. Ancak, bu sonuçlar prospektif ve klinik çalışmalar ile doğrulanmalıdır.
\end{abstract}

Anahtar Kelimeler: Depresyon, hiperemezis gravidarum, anksiyete

Abstract

Aim: Hyperemesis gravidarum (HG) refers to a disorder of early pregnancy that manifests with extreme, difficult-to-treat nausea and vomiting. Its pathogenesis is largely obscure, and studies investigating its link with anxiety depression have remained inconclusive. Herein, we aimed to study the depression and anxiety levels of a Turkish population of pregnant women with hyperemesis gravidarum.

Patients and Methods: This was a prospective sectional study conducted at our Department of Obstetrics and Gynecology between January 2011 and June 2013. There were 50 pregnant women with HG and 50 healthy pregnant women without any history of nausea and vomiting, who were matched with the study group for age, parity, and body mass index. All subjects underwent baseline laboratory investigations including serum TSH.

Results: The two groups were comparable with regard to the demographic and obstetric parameters and baseline laboratory investigations although the HG group had significantly greater mean serum AST and TSH levels ( $p=0.015$ and $p=0.0001$, respectively). Additionally, the HG group had significantly greater BDI and BAI scores compared to the controls $(p=0.0001$ and $p=0.0001$, respectively)

Conclusion: Our results have shown that psychological stress may be one of the causes of HG. For this reason, emotional states as well as medical conditions of HG patients during pregnancy should be considered. However, these results should be confirmed by prospective and clinical studies.

Key words: Depression, hyperemesis gravidarum, anxiety

\section{GíRiş}

Hiperemezis gravidarum (HG) erken gebelikte şiddetli, inatçı bulantı ve kusma ile karakterize bir hastalık olup dehidrasyon, ketonüri, sıvı-elektrolit dengesizliği, beslenme bozukluğu ve kilo kaybı ile ilişkilidir (1). Gerek farklı ülkeler arasında, gerekse ülkelerin kendi içinde $H G$ prevalansında belirgin değişkenlik olduğu bildirilmiştir.Eliakim'e göre HG prevalansı \% 0,3 ile \% 2 arasında değişmektedir (2).
HGgebelikleilişkili hastalıkların en yaygın olanlarından biri olup, gebelik sırasında annenin hastaneye yatışının en önemli nedenidir (3). Genellikle sık acil servis ziyaretlerine ve bazen intravenöz hidrasyon için tekrarlayan hastane yatışına yol açar. Annenin kilo alımının bozulması, düşük doğum ağırlığı ve gebelik haftasına göre bebeğin gelişiminin daha geri olması ile ilişkilidir (4). En çok yüksek human koryonik gonadotropin seviyeleri ile olmak üzere HG, değişik
Yazışma Adresi: Esin Kasap, Ozel Tınaztepe Hastanesi Kadın Hastalıkları ve Doğum Kliniği, Izmir e-posta: dresincelik@windowslive.com

Atıf yapmak için: Kasap E. Hiperemezis Gravidarumlu Hastalarda Anksiyete ve Depresyon Test Skorları. Selcuk Med J 2018;34(4): 155-159
Açıklama: Yazar bu makalede bahsedilen herhangi bir ürün, aygıt veya ilaç ile ilgili maddi çıkar ilişkisine sahip değildir. Araștırma, herhangi bir dış organizasyon tarafından desteklenmedi. Yazar calışmanın birincil verilerine tam erişim izni vermek ve derginin talep ettiği takdirde verileri incelemesine izin vermeyi kabul etmektedir. 
endokrinolojik patolojilerle birlikteliği rapor edilmişse de; HG etiyolojisi ve patogenezi belirsizdir ve biyolojik, psikolojik ve sosyoekonomik temeller üzerinde birden fazla faktöre bağlı olabilir. Endokrinolojik patolojilere ek olarak, gastrointestinal disfonksiyon, hepatik anomaliler, lipid değişiklikleri ve enfeksiyon gibi diğer patolojik faktörler de bu tıbbi durumun etyolojisi ve patofizyolojisinde rol oynayabilir (1-5). Doğurganlık çağındaki kadınların artmış depresyon ve anksiyete riski altında oldukları iyi bilinmektedir (6) ve gebelik depresif dönem riskini artırabilir (5).

$\mathrm{Bu}$ bilgiler ışığında biz de bu çalışmamızda hiperemezis gravidarum'lu (HC) gebelerde anksiyete ve depresyon sıklık ve düzeylerini araştırmayı amaçladık.

\section{HASTALAR VE YÖNTEM}

Bu prospektif kesitsel çalışma; hastanemizin Kadın Hastalıkları ve Doğum kliniğinde; Ocak 2011 ile Haziran 2013 arasında yapıldı. Tüm katılımcılara çalışma hakkında bilgi verildi ve tümü çalışmaya katılmayı kabul etti. Çalışma protokolü, hastanenin medikal etik komitesi tarafından kabul edildi. Çalışma grubu 50 adet HG tanısı alıp Doğum Servisimize yatırılan gebeden oluşurken,bulantı ve kusması olmayıp rutin antenatal bakım için doğum polikliniğimize başvuran 50 sağlıklı gebe kontrol grubunu oluşturdu. Hasta ve sağlıklı gebeler yaş, parite, vücut kitle endeksi ve gebelik haftalarına göre eşleştirildiler. Çalışmaya alınan tüm hastalarda tek gebelik vardı. Dahil edilme kriterleri şunlardı: kesin olarak bilinen son adet tarihi ve ultrason ile doğrulanan tek, canlı intrauterin gebelik olması; çalışmaya katılmak için yazılı onam ve gönüllülüğün olması. Dışlama kriterleri ise şu şekildeydi: bir tıbbi problemin (örneğin endokrin anormallikleri, gastrointestinal, kardiyovasküler ve pulmoner hastalıklar) ya da daha önce tanı konmuş psikiyatrik bir sorunun (örneğin depresyon, anksiyete, bipolar bozukluk, deliriyum, yeme bozuklukları ve psikotik bozukluk) olması, çoklu gebelik, abortus imminens, gestasyonel trofoblastik hastalık ve ektopik gebelik gibi bilinen bir obstetrik komplikasyonun olması, test sonuçlarını etkileyebilecek herhangi bir sistemik hastalık olması ya da ilaç (son 6 ayda kullanılan antidepresanlar, antipsikotikler veya diğer psikiyatrik ilaçlar) kullanıyor olmaktı.

HG tanısı klinik kriterlere (günde en az 3 kusma döneminin olması, toplam vücut ağırlığının \%5'inin kaybı ve ketonüri) göre konuldu ve gastroenterit, kolesistit, akut pankreatit, gastrik çıkış yolu obstrüksiyonu, piyelonefrit, primer hipertiroidizm, primer hiperparatiroidizm ya da karaciğer disfonksiyonu gibi diğer kusma nedenleri dışlandı.

Fetal biyometre, plasental yerleşim, amniyon sıvısı dahil tüm olgulara ultrason yapıldı ve ilgili obstetrik durumlar (örneğin ikiz gebelik, molar gebelik ve gecikmiş düşük) dışlandı.

Tüm hastalarda başvuruda kan örnekleri alınarak biyokimya testleri ve hemogram çalışıldı. Açlık ketozunu tespit için idrarda ketonüri bakıldı. Veriler, başvuru anında ve bir kere hastaların psikolojik durumlarını belirlemek amacıyla eğitimli görüşmeciler tarafından yapılan yüz yüze görüşmeler sırasında doldurulan bir dizi form yardımıyla toplandı. İlk form, hastaların demografik özelliklerine dönük sorulardan oluşmaktaydı. İkinci form ise, Beck Depresyon Envanteri'nin (BDE) ve Beck Anksiyete Envanteri'nin (BAE) Türkçe versiyonlarını içermekteydi. BDE ve BAE, sırasıyla depresyon ve anksiyete semptomlarının şiddetini değerlendirmek için kullanılan 21 maddelik kendi kendine rapor etme araçlarıdır (7-8). Her bir yanıta, semptom şiddetini belirtmek üzere 0 (hiç sıkıntılı değil) ile 3 (çok sıkıntılı) arasında bir skor verilir. Hisli'ye göre, Türk popülasyonu için 17 puan ya da fazlası depresyonu göstermektedir (9). Depresyon seviyesini belirlemek için biz de bu eşik skorlarını kullandık.

BAE'nin Türk toplumundaki geçerlilik ve güvenilirliği Ulusoy et al. (10) tarafından gösterilmiştir.

\section{Vücut kitle indeksi (VKi)}

VKI, Hastaların kilolarının (kg) boy değerlerinin karesine $\left(\mathrm{m}^{2}\right)$ bölünmesi ile hesaplandı $\left(\mathrm{kg} / \mathrm{m}^{2}\right)$.

\section{İstatistiksel Analiz}

İstatistiksel analizler SPSS for windows version 17.0 ile yapıldı. Değişkenlerin normal dağılıma uygunluğu analitik yöntemler (Kolmogorov-Smirnov/Shapiro-Wilk testleri) kullanılarak incelendi. Tanımlayıcı istatistikler, kategorik veriler için frekans (sayı) ve yüzde, sürekli değişkenler için ortalama \pm standart sapma veya medyan (IQR) verilerek yapıldı. Sürekli değişkenler arasındaki bağımsız grupların karşılaştırılmasında normal dağılımda bağımsız gruplarda T testi, normal dağılmayan durumda Mann-Whitney $U$ testi ile analiz edildi. Kesikli değişkenler arasında grupların karşılaştırılmasında Pearson ki-kare testi veya Fisher Kesin Ki-Kare testi uygulandı. p-değerinin 0.05'in altında olduğu durumlar istatistiksel olarak anlamlı sonuçlar şeklinde değerlendirildi.

\section{BULGULAR}

Çalışma ve kontrol grubundaki gebeler; yaş, gebelik haftası, parite, vücut kitle indeksi açısından 
Table 1. Hiperemezis ve sağlıklı kontrol gruplarının demografik verileri

\begin{tabular}{lccc}
\hline Değişkenler & Kontrol $(\mathbf{n}=\mathbf{5 0})$ & Hiperemezis $(\mathbf{n}=\mathbf{5 0})$ & p-Değerleri \\
\hline Yaş & $28.9 \pm 4.8$ & $28.1 \pm 4.5$ & $0.392^{*}$ \\
Gest. Hafta & $7.6 \pm 1.3$ & $7.7 \pm 1.4$ & $0.880^{*}$ \\
BMI & $25.2 \pm 3.9$ & $25.3 \pm 4.2$ & $0.943^{*}$ \\
Parite & Sayı $(\%)$ & Sayı $(\%)$ & \\
0 & $22(44.0)$ & $19(38.0)$ & $0.560^{* *}$ \\
1 & $24(48.0)$ & $23(47.0)$ & \\
2 & $4(8.0)$ & $7(11.0)$ & \\
3 & $0(0.0)$ & $1(1.0)$ & $0.006^{* * *}$ \\
Planlı Gebelik & Sayı $(\%)$ & Sayı $(\%)$ & \\
Var & $47(94.0)$ & $36(72.0)$ & \\
Yok & $3(6.0)$ & $14(28)$ & \\
Ketonüri & Sayı $(\%)$ & Sayı $(\%)$ & $0.0001^{* *}$ \\
0 & $50(100.0)$ & $0(0)$ & \\
1 & $0(0)$ & $20(40.0)$ & \\
2 & $0(0)$ & $18(36.0)$ & \\
3 & $0(0)$ & $12(24.0)$ &
\end{tabular}

HG: Hiperemezis gravidarum

* Bağımsız T test; $\quad$ ** Pearson Ki-Kare; ${ }^{* * *}$ Fisher Ki-Kare test

karşılaştırıldı. Yaş, gebelik haftası, vücut kitle indeksi ve parite açısından gruplar arasında istatistiksel olarak anlamlı farklılık saptanmadı (Tablo 1). Bulgular Tablo 1'de ayrıntılı olarak verilmiştir.Tüm katılımcılar evli ve gebeliğin ilk trimesterindeydiler.

Gruplar arasında, kontrol grubuna göre HG grubunda anlamlı şekilde daha yüksek olan ortalama serum Aspartat Aminotransferaz (AST) düzeyi $(p=0,015)$ ve Tiroid Uyarıcı Hormon (TSH) düzeyi $(P=0.0001)$ dışında bazal laboratuar testleri yönünden fark yoktu (Tablo 2).

HG tanısıyla tedavi alan grup ve kontrol grubundaki gebeler karşılaştırıldığında; HG tanısıyla tedavi alan grupta kontrol grubuna göre BDE ve BAE skoru anlamlı yüksek saptandı (sırasıyla $p=0,0001$ ve $p=0,0001)$ (Şekil 1A-1B). Her iki grubun ortalama BDE ve BAE skorları Tablo 3'te verilmiştir. HG grubunda günlük ortalama kusma atağı sayısı 5,7 idi (aralık 1-10). Çalışma grubundaki tüm hastalar hiperemezis tedavisi için yataklı servise yatırıldılar. Hastanede kalış süresi ortalama 1,4 gün olup 1 ile 7 gün arasında değişmekteydi. Hiçbir hastada parenteral besleme gereksinimi duyulmadı.

\section{TARTIŞMA}

$\mathrm{Bu}$ çalışma, gebelikleri sırasında şiddetli kusma atakları yaşayan HG lu gebelerin, sağlıklı antenatal kontrol grubu gebeler ile karşılaştırıldıklarında belirgin şekilde daha fazla anksiyete ve depresyona sahip olduklarını göstermiştir. Hisli (9), Türk popülasyonu için Beck depresyon skalasında 17 ya da daha yüksek bir puanı depresyon limiti olarak tanımlamıştır. $\mathrm{Bu}$ çalışmanın en önemli bulgusu, HG'li hastaların yarısından fazlasının orta ya da şiddetli derecede depresyonu olması ve bu prevalans oranlarının sağlıklı kontrollere göre daha yüksek olmasıdır. HG'li gebelerde bu yüksek depresyon düzeyi yetersiz gıda alımına, enerji eksikliğine ve şiddetli yorgunluğa,

Table 2. Hiperemezis ve kontrol gruplarının laboratuar verileri

\begin{tabular}{llll}
\hline Parametreler & Kontrol $(\mathbf{n = 5 0}$ & Hiperemezis $(\mathbf{n}=\mathbf{5 0})$ & p-değerleri $\left(^{*}\right)$ \\
\hline $\mathrm{Hb}(\mathrm{g} / \mathrm{dl})$ & $12.2 \pm 1.4$ & $12.5 \pm 1.2$ & 0.173 \\
$\mathrm{Wbc}(103 / \mathrm{ml})$ & $9.1 \pm 2.2$ & $9.0 \pm 2.2$ & 0.821 \\
$\mathrm{Plt}(103 / \mathrm{ml})$ & $252.7 \pm 54.4$ & $247.3 \pm 78.4$ & 0.692 \\
$\mathrm{Na}(\mathrm{mmol} / \mathrm{l})$ & $137.1 \pm 3.1$ & $138.7 \pm 5.7$ & 0.077 \\
$\mathrm{~K}(\mathrm{mmol} / \mathrm{l})$ & $4.1 \pm 0.4$ & $4.5 \pm 1.4$ & 0.050 \\
$\mathrm{ALT}(\mathrm{U} / \mathrm{l})^{* *}$ & $15(7)$ & $16(17)$ & 0.403 \\
$\mathrm{AST}(\mathrm{U} / \mathrm{l})^{* *}$ & $164)$ & $19(14)$ & 0.098 \\
Üre $(\mathrm{mg} / \mathrm{dl})$ & $20.8 \pm 5.2$ & $22.6 \pm 8.7$ & 0.226 \\
Kreatinin $(\mathrm{mg} / \mathrm{dl})$ & $0.69 \pm 0.7$ & $0.61 \pm 0.1$ & 0.468 \\
TSH $(\mu \mathrm{lU} / \mathrm{ml})$ & $1.85 \pm 0.9$ & $2.5 \pm 0.94$ & 0.0001 \\
\hline
\end{tabular}

HG: Hyperemezis gravidarum; ALT/AST: Medyan (IQR) * Bağımsız T test 


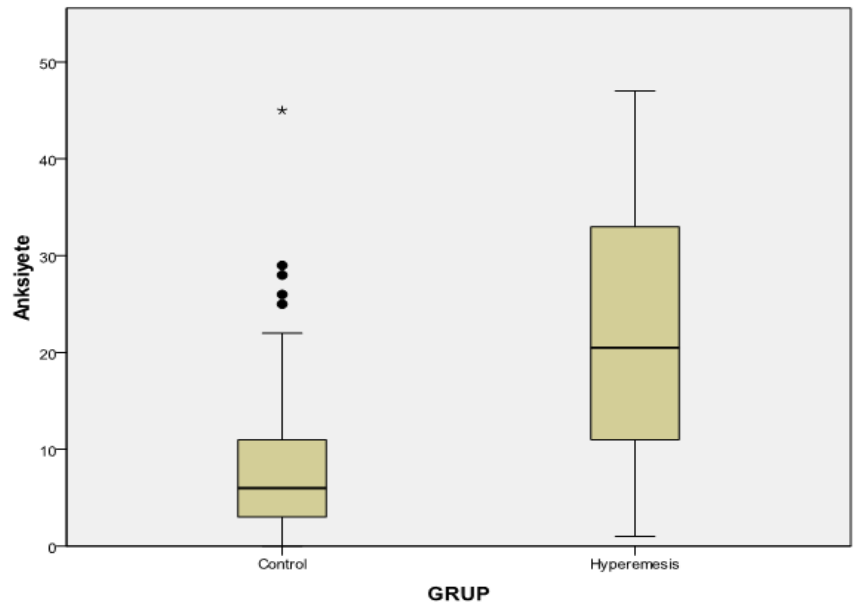

Şekil 1A. Hiperemezis ve Kontrol Gruplarında Anksiyete Düzeylerinin Karşılaştırılması

sosyal hayat eksikliğine, bulantı ve kusmanın doğum öncesi kesileceğine dair umudun kaybolmasına ve bebeğin beslenme bozukluğuna neden olabilir.

Literatürde Swallow et al. (11) erken gebelikte bulantı ve kusmanın psikiyatrik morbidite ile bağlantılı olduğunu göstermiştir. Yazarlar, bulantı ve kusmanın şiddetinin anksiyete/uykusuzluk ve depresyon düzeyiyle bağımsız şekilde ilişkili olduğunu bildirmiştir. Benzer şekilde, Poursharif et al. (12) HG lu gebelerde anksiyete ve depresyona bağlı bazı belirtilerin gebelikten sonra da görülmeye devam ettiğini vurgulamışlardır. Kim et al. (13) incelemesinde, HG'lu kadınlarda yaşam kalitesinin ciddi şekilde bozulduğunu vurgulayarak bu gebelerin psikiyatrik açıdan da değerlendirilmesi gerektiğini önermişlerdir. Diğer çalışmalar ise, bunun tersine, gebelik sırasında HG'si olan kadınlarda psikiyatrik hastalıklarda artış tespit etmemişlerdir (14-15). Karaciğer hasarı HG hastaların yarısında görülür (16-17) ve klinik belirtilerin şiddeti, karaciğer enzim yüksekliği derecesi ile uyumlu olduğu bildirilmiştir. Karaciğer hastalığı ile birliktelik gösteren HG da klinik tablo; hafif aminotransferaz yüksekliğinden ciddi aminotransferaz yüksekliğine ve ara sırada sarılığa kadar değişebilir (17-18). Bizde kendi çalışmamızda kontrol grubuna göre HG grubunda anlamlı şekilde

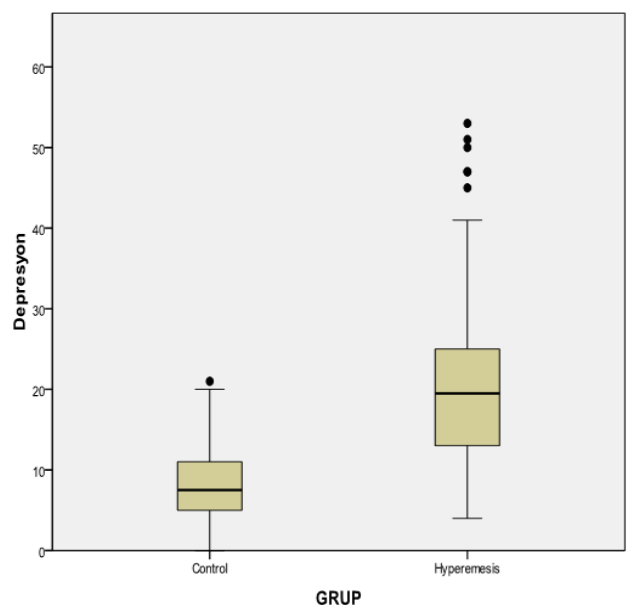

Şekil 1B. Hiperemezis ve Kontrol Gruplarında Depresyon Düzeylerinin Karşılaştırılması

serum Aspartat Aminotransferaz (AST) düzeyinde yükseklik tespit ettik.

Gebeliğinde inatçı bulantı kusması olan hastaların çoğunda geçici hipertroidi saptanmıştır (19). Nedeni tam olarak belirlenememekle birlikte yüksek HCG düzeylerinin kusmanın şiddeti ve Troid Stimülasyonu arasında anlamlı bir korelasyon olduğu tespit edilmiştir (20-23). Bizde kendi çalışmamızda kontrol grubuna göre HG grubunda anlamlı şekilde serum TSH düzeyinde yükseklik tespit ettik.

Psikolojik ya da psikiyatrik morbiditenin HG'nin sebebi mi sonucu mu olduğu açık değildir. Geçmişte, gebelik sırasında şiddetli kusma sıklıkla annenin istenmeyen gebeliğe duyduğu hıncın bir dışavurumu olarak algılanırdı. Duygusal immatürite, kuvvetli anne bağlılığı ve gebeliğe bağlı anksiyete ve gerilimi içine alan çeşitli psikolojik stresler hiperemezis ile ilişkilendirilmiştir (12). Çalışmamızın birtakım önemli eksiklikleri mevcuttur. Bunlardan biri az sayıda hiperemezisli gebe kadının araştırmaya dahil edilmesi, araştırmanın tek bir merkezle sınırlı olması ve bu bulguları desteklemek için daha geniş çaplı araştırmalara intiyaç olmasıdır.

\section{SONUÇ}

HG,genetik ve hormonal etiyolojiler kadar

Table 3. Hiperemezis ve kontrol gruplarında Depresyon ve Anksiyete skorlarının karşılaştırılması

\begin{tabular}{llll}
\hline Parametreler & Kontrol $(\mathbf{n = 5 0 )}$ & Hiperemezis $(\mathbf{n = 5 0 )}$ & p- Değerleri \\
\hline BDE & $7.98 \pm 5.23$ & $22.38 \pm 13.32$ & $0.0001^{*}$ \\
BAE & $8.64 \pm 8.90$ & $21.96 \pm 12.41$ & $0.0001^{*}$ \\
\hline
\end{tabular}

HG: Hiperemesis gravidarum;BDI: Beck Depresyon Envanteri; BAI: Beck Anksiyete Envanteri

* Bağımsız T test 
psikiyatrik bir etiyolojiye de sahip tıbbi hastalıktır (2425). Sonuç olarak biz de yaptığımız çalışmamızda, HG'lu gebelerde anksiyete ve depresyon düzeylerini anlamlı olarak yüksek bulduk. HG'lu bir gebenin tedavisi düzenlenirken gebenin psikiyatrik açıdan da değerlendirilmesi göz önünde bulundurulmalıdır. Sonuçlarımız, psikolojik stressin HG un nedenlerinden biri olabileceğini göstermiştir. Ancak, bu sonuçlar prospektif ve klinik çalışmalar ile doğrulanmalıdır.

Çıkar Çatışması: Çalışmada herhangi bir çıkar çatışması yoktur.

Finansal Çıkar Çatışması: Çalışmada herhangi bir finansal çıkar çatışması yoktur.

Yazışma Adresi: Esin Kasap,

Adres: Özel Tınaztepe Hastanesi Kadın Hastalıkları ve Doğum Kliniği, Buca, Izmir, Türkiye 35100.

e-posta:dresincelik@windowslive.com

\section{KAYNAKLAR}

1. Verberg MF, Gillott DJ, Al-Fardan N, et al. Hyperemesis gravidarum, a literature review. Hum Reprod Update 2005;11(5):527-39.

2. Eliakim R, Abula a O, Sherer DM. Hyperemesis gravidarum: A current review. Am J Perinatol 2000;17(4):207-18.

3. Ismail SK, Kenny L. Review on hyperemesis gravidarum. Best Pract Res Clin Gastroenterol 2007;21(5):755-69.

4. Dodds L, Fell DB, Joseph KS, et al. Outcomes of pregnancies complicated by hyperemesis gravidarum. Obstet Gynecol 2006;107(2 Pt 1):285-92.

5. Tan PC, Vani S, Lim BK, et al. Anxiety and depression in hyperemesis gravidarum: Prevalence, risk factors and correlation with clinical severity. Eur J Obstet Gynecol Reprod Biol 2010;149(2):153-8.

6. Pedersen W. Abortion and depression: A population-based longitudinal study of young women. Scand J Public Health 2008;36(4):424-8.

7. Beck AT. An inventory for measuring depression. Arch Gen Psychiatry 1961;4:561-71.

8. Beck AT, Epstein N, Brown G, et al. An inventory for measuring clinical anxiety: Psychometric properties. J Consult Clin Psychol 1988;56(6):893-7.

9. Hisli N. Beck depresyon envanterinin geçerliliği üzerine bir çalışma. Psikoloji Dergisi 1988;22:118-26.

10. Ulusoy $\mathrm{M}$, Sahin $\mathrm{NH}$, Erkmen $\mathrm{H}$. Turkish version of the Beck Anxiety Inventory: Psychometric properties. J Cogn Psychother 1998;12(3):23-9.

11. Swallow BL, Lindow SW, Masson EA, et al. Psychological health in early pregnancy: Relationship with nausea and vomiting. J Obstet Gynaecol 2004;24(1):28-32.

12. Poursharif B, Korst LM, Fejzo MS, et al. The psychosocial burden of hyperemesis gravidarum. J Perinatol 2008;28(3):176-81.

13. Kim DR, Connolly KR, Cristancho P, et al. Psychiatric consultation of patients with hyperemesis gravidarum. Arch Womens Ment Health 2009;12(2):61-7.

14. Jahangiri F, Hirshfeld-Cytron J, Goldman K, et al. Correlation between depression, anxiety, and nausea and vomiting during pregnancy in an in vitro fertilization population: a pilot study. J Psychosom Obstet Gynaecol 2011;32(3):113-8.

15. Kramer J, Bowen A, Stewart N, et al. Nausea and vomiting of pregnancy: Prevalence, severity and relation. MCN Am J Matern Child Nurs. 2013;38(1):21-7.

16. Ahmed KT, Almashhrawi AA, Rahman RN, et al. Liver diseases in pregnancy: Diseases unique to pregnancy. World J Gastroenterol 2013;19:7639-46.

17. Abell TL, Riely CA. Hyperemesis gravidarum. Gastroenterol Clin North Am 1992;21:835-49.

18. Conchillo JM, Pijnenborg JM, Peeters P, et al. Liver enzyme elevation induced by hyperemesis gravidarum: Aetiology, diagnosis and treatment. Neth J Med 2002;60:374-8.

19. Goodwin TM, Montro M, Mestman JH. Transient hyperthyroidism and hyperemesis gravidarum: Clinical aspects. Am J Obstet Gynecol 1992; 167: 648-52.

20. Hershman JM, Lee HY, Sugawara M, et al. Human chorionic gonadotropin stimulates iodide uptake, adenylate cyclase and deoxyribonucleic acid synthesis in cultured rat thyroid cells. J Clin Endocrinol Metab 1988;67:74-9.

21. Yoshimura M, Hershman JM. Thyrotropic action of human chorionic gonadotropin. Thyroid 1995;5:425-34.

22. Mori M, Amino N, Tamako $\mathrm{H}$, et al. Morning sickness and thyroid function in normal pregnancy. Obstet Gynecol 1988;72:355-9.

23. Goodwin TM, Hershman JM, Cole L. Increased concentration of the free beta -subunit of human chorionic gonadotropin in hyperemesis gravidarum. Acta Obstet Gynecol Scand 1994;73:770-2.

24. Uguz F, Gezginc K, Kayhan F, et al. Is hyperemesis gravidarum associated with mood, anxiety and personality disorders: A case-control study? Gen Hosp Psychiatry 2012;34(4):398-402.

25. Fejzo MS, Macgibbon K. Hyperemesis gravidarum: It is time to put an end to the misguided theory of a psychiatric etiology. Gen Hosp Psychiatry 2012;34(6):699-70. 